DOI https://doi.org/10.30525/978-9934-26-000-1-35

\title{
ДОКУМЕНТАЛЬНИЙ ФІЛЬМ «УКРАЇНА. ПОВЕРНЕННЯ СВОЄЇ ІСТОРІЇ» VS ІДЕОЛОГІЧНОЇ ПРОПАГАНДИ ІМПЕРІЇ
}

\author{
Яблонський М. Р. \\ кандидат наук з сочіальних комунікацій, \\ старший викладач кафедри соціальних комунікаціий \\ Волинський національний університет імені Лесі Украӥнки \\ м. Луизьк, Украӥна
}

У формуванні суспільної думки ідеологічна пропаганда завжди відігравала провідну роль. У добу доінформаційного суспільства таку функцію виконувала історія. Закономірно, що офіційна історія імперії покликана утвердити монархію, продемонструвавши вибраність панівного народу. Однак всесвітня історія презентує і протилежні приклади, коли культура завойованого народу та його історія випереджували рівень загарбника: такою $є$ історія Стародавньої Греції в Римській імперії, України - в Російській. Тому ідеологічна машина імперії свідомо формує фальсифікований канон історії, в якому всупереч істині буде презентовано вищість привілейованого панівного народу. Заради такої мети державною машиною легалізовано брудні технології.

Очистити такий пропагандистський намул має на меті документальний фільм А. Галімова «Україна. Повернення своєї історії» (2016), адже те, що було сформовано Російською імперією, успадковано, доповнено й ефективно використано і радянською системою, i сучасним північним сусідом. Сучасна інформаційна війна активізувала потребу ревізії імперського канону старшого брата й усіх, пов'язаних із цією проблемою, складників.

Сюжети трьох серій документального фільму А. Галімова презентують взаємозв'язок людських доль і суспільних катаклізмів. Так, Лідія Гудзенко, вчителька української мови з Києва, після того, як 2015 р. розсекретили архів ЦК Компартії України, прагне дізнатися про свого діда - відомого етнографа Антона Онищука, заарештованого 1937 р. як ворог народу.

Як з'ясувалося, слідча справа етнографа Антона Онищука із висновком про розстріл ворога народу, як і інших українських етнографів, пов'язана 3 масштабними фальсифікаціями історії України. Українські науковці володіли інформацією, яка руйнувала радянську ідею спільної колиски братніх народів, імперську - про велич царської династії (аналогічна концепція - в основі ідеї «русского мира»). Святині Київської Русі забезпечували тисячолітню історію імперії, але відкриття в археології та антропології доводили тільки українське коріння 
Київської держави. Зокрема це висновки дослідження саркофагу Ярослава Мудрого 1936 р.

Серед фактів, які руйнували ідею тисячоліття імперії, дослідження скелета жінки, похованої разом із Ярославом Мудрим. Ленінградський антрополог Вульф Гінзбург зробив висновок, що це рештки шведської принцеси Інгігерди, дружини князя. Однак це суперечило російським історичним джерелам, відповідно до яких іiі поховано в Новгороді як канонізовану православну святу Анну Новгородську. У фільмі наголошується: «Для радянських ідеологів було принципово, щоб правителі Київської Русі були поховані і в Україні, і в Росії: це підкреслювало спільну історію Особливо, якщо йшлося про подружжя Інгігерди та Ярослава Мудрого, який зробив Русь наймогутнішою державою тих часів» [1]. Неля Куковальська, генеральний директор заповідника «Софія Київська», акцентує на тому, що це подружжя є родоначальником усіх монарших родів Європи; це пояснює особливу увагу російської пропаганди до цих ключових фігур історії, адже спільність із ними означає спорідненість із європейськими монархами. «Родинні зв'язки зробили Інгігерду найвпливовішою жінкою стародавньої Свропи» [1], зауважує А. Галімов.

У фільмі до дослідження історії Інгігерди, їі поховання, ідентифікації останків, реконструкціяї обличчя, а також причини, чому вона канонізована російським православ'ям, залучено шведський рукопис XIII ст., у якому міститься опис Інгігерди, російську історіографію, свідчення вчених, які досліджували поховання Анни в Новгороді, висновки антропологів, лабораторні дослідження. Професор історії, богослов Антуан Аржаковський (Париж) наголошує, що Анна Новгородська канонізована після Флорентійського собору 1439 р., відкинутого Москвою, що й обумовило відокремлення московської церкви, навколо якої почне формуватися московська держава, заклавши підвалини ідеї «русского мира». Московські священники починають перетягувати 3 українського православного календаря святих, - усіх тих, хто стояв біля витоків української держави; це мало сформувати суспільну думку про спільний пантеон святих, спільну територію і спільного імператора.

Доречно нагадав проф. Сергій Сегеда, як росіянами були привласнені українські билини й зокрема богатиря Іллю Муромського, що насправді походив із українського Морівська, який знаходиться на півдорозі з Києва до Чернігова.

Історик Ярослав Затилюк звертає увагу на «Синопсис» як продукт російської пропаганди, виданий 20 років після Переяславської ради.

Історичні карти засвідчують, що до 1654 р. ні на одній карті Московія не називається Руссю. У кінці XVIII ст. назва Русь остаточно затверджується за Росією, для цього процесу достатньо було трьох століть - від поч. XVI ст. до кінця XVIII ст. Тільки на території Русько- 
го воєводства на Західній Україні з центрами Галич і Львів залишається етнонім Русь.

Історик Мирослав Волощук наголошує, що король Русі Данило не вписувався в концепцію російської історії, як і віднайдені артефакти із зображенням двоголового орла як символу держави ще часів Данила Галицького. Пошуки корони короля Данила в Холмі та Перемишлі привідкрили таїну завіси. Священник Перемишльської єпархії української греко-католицької церкви отець Динько протягом 15 років переховував корону, але секретні агенти Міністерства громадської безпеки Польщі вийшли на нього й домоглися зізнання. Тепер, очевидно, корону треба шукати в Москві.

В середині XIX ст. в Києві була створена Київська археографічна комісія, яка мала політичне завдання - за допомогою історичних пам’яток, документів довести, що українська частина Російської імперії споконвіку належала до російської традиції; по суті, це питання «русского мира». Очільник комісії - сумнозвісний Юзефович. Однак стародавні графіті в Софії Київській (їх понад 7 тис.), які датуються поч. ХІ ст., засвідчують існування української мови, заперечуючи ідею спільної давньоруської мови та спільної давньоруської держави.

I за радянських часів секретна група істориків у 1945 р. писала курс історії України. Одна 3 настанов - засудження Івана Мазепа продовжує імперську традицію. Після битви під Полтавою Петро I наказав знищити всі портрети Івана Мазепи, виготовити медаль Іуди, яка призначалася Мазепі, та відлучити гетьмана від церкви. Прокляття і досі виголошують у деяких церквах московського патріархату. Хоча насправді першим зрадив таки Петро: його просив Мазепа про підтримку, якщо шведи підуть у наступ через Україну, але відповідь була вкрай негативною. Звичайно, ця документально засвідчена інформація не потрапляла на сторінки історичних досліджень. Як і те, що нищення Батурина заперечують російські історики. У радянські часи були заборонені будь-які розкопки в цій колишній гетьманській резиденції. Сучасні археологи, патологоанатоми доводять, що причина смерті батуринців була насильницькою.

У пошуках істинного зображення Мазепи звертаються до описів гетьмана в історичних джерелах, до його живописних портретів. 1927 р. етнограф Борис Пилипенко віднайшов дзвін, вилитий за кошти Мазепи, на якому є зображення гетьмана. Через те, що Борис Пилипенко зробив фото дзвона, його арештували. Тільки 2015 р. стало відомо, що дзвін знаходиться на дзвіниці Нікольського собору в Оренбурзі. Вдалося зробити фото цього зображення гетьмана на дзвоні.

У другій частині фільму зреалізоване дослідження біографії етнографа Антона Онищука, який проводив свої студії в карпатському селі Черник, але, перейнявшись тяжким становищем місцевих людей, вирішив організувати школу, де він і навчав. У сучасному селі організо- 
ваний музей етнографа Антона Онищука, тут знаходиться його праця «Основи гуцульської демонології». Антон Онищук, повіривши пропаганді, переїхав в радянську Україну. Його етнографічне дослідження стане причиною страти, бо доводило українську національну ідентичність. Він розстріляний у Биківні, як і тисячі інших науковців, письменників, громадських діячів. «Нас усіх відірвали від коріння» [2] висновок історії Антона Онищука.

У фінальній серії [2] постануть результати тривалої роботи групи працівників кафедри судової медицини Медичного університету ім. Кароля Марцинковського (Познань) - реконструйоване зображення Інгігерди. За допомогою сучасних технологій українські дослідники відновили портрет Мазепи, який презентує образ успішного українця. Висновок фільму дослідження - ідея Києвоцентричної держави, яка живе понад тисячу років в людях, культурі, мові, церкві.

Отже, фільм А. Галімова (2016) «Україна. Повернення своєї історії» (2016) руйнує імперську стратегію фальсифікації історії України.

\section{Література:}

1. Україна. Повернення своєї історії. Частина 1. URL: https:// www.youtube.com/watch? $\mathrm{v}=\mathrm{j} 3 \mathrm{LhEdsdAo8} \& \mathrm{t}=791 \mathrm{~s} \quad$ (дата 24.11.2020).

2. Україна. Повернення своєї історії. Частина 2. URL: https:// www.youtube.com/watch? $v=N x G K w L y z o 8 s$ (дата звернення: 24.11.2020).

3. Україна. Повернення своєї історії. Частина 3. URL: https:// www.youtube.com/watch?v=9YUebfDQPsY (дата звернення: 24.11.2020). 